\title{
Self-confidence and hardiness towards work readiness: Study on vocational high school students
}

Tentama, Fatwa $\measuredangle$

Universitas Ahmad Dahlan Yogyakarta, Indonesia (fatwa.tentama@psy.uad.ac.id)

Subardjo, Subardjo

Universitas Ahmad Dahlan Yogyakarta, Indonesia (subardjo@law.uad.ac.id)

Mulasari, Surahma Asti

Universitas Ahmad Dahlan Yogyakarta, Indonesia (surahma.mulasari@ikm.uad.ac.id)

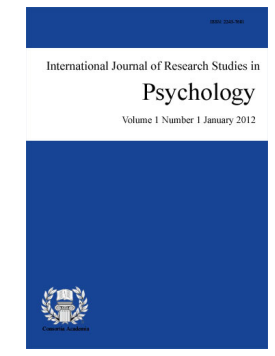

ISSN: $2243-7681$ Online ISSN: 2243-769X

OPEN ACCESS

Merdiaty, Netty

Universitas Bhayangkara Jakarta Raya, Indonesia (netty.merdiaty@dsn.ubharajaya.ac.id)

Received: 5 March 2019

\section{Abstract}

Work readiness is an essential factor needed by students to enter the workforce. This study aims to determine the effect of self-confidence and hardiness on students' work readiness. The population in this study were all students of Grade XII State Vocational High School 1 Seyegan, Sleman Yogyakarta. The sampling technique is cluster random sampling. The sample in this study consisted of 6 classes obtained randomly with 174 students in class XII. Data collection was conducted using several tools, namely the work readiness scale, the self-confidence scale, and the hardiness scale. The data analysis technique used in the study is multiple linear regression analysis. The results of the data analysis indicated a very significant effect of self-confidence and hardiness on work readiness, with an F value of 40.135 and a significance level $(p)$ of .000 . The higher the student's confidence and hardiness, the better the work readiness. Vice-versa, the lower the student's confidence and hardiness, the lower the work readiness. The role of self-confidence in work readiness is more dominant than hardiness.

Keywords: hardiness; self-confidence; work readiness 


\section{Self-confidence and hardiness towards work readiness: Study on vocational high school students}

\section{Introduction}

Vocational High Schools are now increasingly favor and expected by the community. This is because the Vocational High School students in the learning process are equipped with the knowledge, understanding and skills needed in the world of work. Getting a job is the primary goal of every person in education. Vocational high school graduates are expected to have competencies that are in accordance with the needs of the workforce and are considered more ready to enter the workforce because in terms of material both theory and practice in Vocational High Schools are applicable and have been given early when compared to High Schools. Vocational education is secondary education that prepares students, especially to work in specific fields. The teaching and learning process in Vocational High Schools includes learning theory and practice carried out in schools and industry. The learning process is expected to produce quality graduates who are ready to work.

One of the goals of Vocational High Schools is to prepare students to enter employment and develop professional attitudes. In addition to preparing a professional workforce, the Vocational High School also prepares students to continue their education to universities according to their fields of expertise. One of the visions of Vocational High Schools is that they are competitive in employment and one of the missions of Vocational Schools is to improve the quality of learning in excellent vocational high schools to produce graduates who are competing in work. Based on the understanding of the vision and goals of the Vocational High School, Vocational High Schools are work-oriented schools, one of which is preparing and providing students with knowledge and skills as skilled workers with expertise that is ready to be applied in work.

The current reality is that many vocational high school students who are not ready to work and become one of the most significant contributors to open unemployment in Indonesia. The results of the Central Bureau of Statistics (2018) show that the open unemployment rate of Vocational High School graduates in Indonesia in February 2014 was $7.21 \%$ and February 2015 increased to $9.05 \%$, then in February 2016 unemployment in Vocational High Schools increased to 9, 84\% and in February 2017 unemployment in Vocational High Schools decreased slightly by $9.27 \%$. The data shows that many students and graduates of Vocational High Schools currently do not have reasonable and appropriate work readiness.

Work readiness is an essential factor that Vocational High School graduates must have to enter the workforce. Some entrepreneurs assess that work readiness is a criterion that can predict potential graduates. Consequently, employers expect graduates to have generic skills and attributes beyond specific disciplinary competencies that reflect graduates' work readiness (Caballero \& Walker, 2010). However, the facts in the field indicate that numerous entrepreneurs find lack of work readiness among graduates that are needed for long-term success (Casner-Lotto \& Barrington, 2006).

Individuals who possess work readiness will strive to improve the mobility of graduates, are flexible, skilled, and qualified to meet the requirements of the workforce (Andrews \& Higson, 2008). Additionally, individuals with work readiness also can put into use their affective skills - utilizing emotional and social attributes combined with work-specific cognitive skills to help optimize their work skills (Bandaranaike \& Willison, 2015). Individuals with work readiness tend to have an easier time identifying career opportunities and getting jobs directly or indirectly (Landrum, Hettich, \& Wilner, 2010).

Work readiness is defined as the ability of individuals to be involved in, or return to, paid work (Innes \& Straker, 2002). According to Mason, Williams, and Cranmer (2009), work readiness is the ownership of commercial skills, knowledge, attitude, and understandings that will enable new graduates to contribute 
productively to the achievement of organizational goals. Work readiness is a skill and attribute that makes individuals ready for success in the workplace. Work readiness is increasingly recognized as an indicator to measure individual potentials in terms of job performance and career progress (Caballero \& Walker, 2010). Work readiness is defined as the necessary skill level and a prerequisite for a job or occupation determined through a work profile or job analysis (Clark, 2015).

Brady (2009) stated that work readiness consists of six aspects. The first aspect is responsibility; this responsibility is related to discipline. Responsible individuals will complete the task on time and strive to comply with established standards. Other forms of responsibility behavior include maintaining work timeliness, meeting work quality standards, focusing on work, working well even if not monitored, and managing work practice equipment to complete tasks. The second aspect is flexibility; flexible individuals can adapt to changes and environmental demands. Flexible individuals can adjust to the demands of work and change. Flexibility includes the ability to be more active with demands, the ability to perform different tasks, the ability to accept various environmental changes, the ability to follow applicable rules and the ability to work overtime. The third aspect is skills, skills including mastery of talents in the fields they already have, ability to understand themselves related to work, ability to use work tools in accordance with usage procedures and efforts to learn new skills.

The fourth aspect is communication; individuals who are ready to work have communication skills that allow individuals to connect interpersonally with the people around them. Communication includes the ability to follow directions in carrying out tasks, the ability to ask for help related to tasks, the ability to cooperate well, have mutual trust, have a supportive attitude, have an open attitude and receive feedback or criticism. The fifth aspect is self-view, which is the belief in one's ability to do a task. In this case, the view of self includes the ability to understand oneself, the ability to respect oneself, the ability to control or control themselves, the ability to evaluate themselves, trust in the ability to do tasks. The last aspect is health and safety; individuals who are ready to work to maintain personal hygiene and neatness. Workers remain alert to be physically and mentally healthy. The occupational health and safety component includes adherence to following policies and ignoring boundaries, practicing health and safety behavior, carrying out tasks in accordance with existing procedures, maintaining personal hygiene and neatness, the ability to control stress and fatigue (Brady, 2009).

\subsection{Self-confidence towards work-readiness}

Raftopoulos, Coetzee, and Visser (2009) state that to have work readiness individuals must have confidence in their abilities. Self-confidence in own skills can improve work readiness, and individuals with self-confidence tend to be better prepared to find work and enter the workforce (Jollands, Jolly, \& Molyneaux, 2012). Li, Li-Tsang, Lam, Hui, and Chan (2006) found that self-confidence has a positive effect on work readiness. Several researchers found that a low level of individual self-confidence will affect the level of work readiness that an individual has (Coetzee \& Esterhuizen, 2010).

Self-confidence shows the extent to which an individual feels capable and have confidence in their decisions and behavior (Bearden, Hardesty, \& Rose, 2001). Self-confidence is seen as an individual's recognition of their ability, love for themselves and the ability to understand their own emotions (Ozbey, 2004). Self-confidence is also an individual's belief in their ability to successfully carry out the tasks given in the identified context (Luthans, Luthans \& Luthans, 2004). Individuals who have self-confidence will have the strength and ability to carry out desired tasks or functions (Brown \& Chronister, 2009). Also, self-confident individuals feel confident about their abilities to organize and implement projects, or a specific set of tasks needed to achieve certain goals or desired outcomes (McGee, Peterson, Mueller, \& Sequeira, 2009).

Aspects of self-confidence, namely 1). Believing in one's abilities is a belief in oneself against all phenomena that occur that are related to the individual's ability to evaluate and overcome the phenomena that occur. 2). Act independently in making decisions that can act in making decisions against oneself that are carried 
out independently or without the involvement of others and can believe in the actions taken. 3). Having a positive sense of oneself is a good judgment from within yourself, both from the views and actions taken that give rise to a positive feeling towards themselves and their future. 3). Dare to express opinions, namely the existence of an attitude to be able to express something in themselves that wants to be revealed to others without any coercion or feeling that can hinder such disclosure (Lauster, 2012).

\subsection{Hardiness towards work readiness}

Another factor that can predict work readiness is hardiness (Bartone, 2006). A study conducted by van Dyk (2015) exploring hardiness properties found that hardiness is a strong predictor of work readiness. Hardiness contributes positively to work readiness, and individuals with hardiness tend to be better prepared for work (Avey, Luthans, Smith, \& Palmer, 2010). Hardiness is a factor that can improve work readiness (Maddi, Matthews, Kelly, Villarreal, \& White, 2012). Individuals with hardiness are more likely to be confident in their skills and abilities to acquire a job in the future (Huang, 2015).

Maddi (2012) defines hardiness as a constellation of personality characteristics that motivate individuals to become stronger, tenacious, stable, and optimistic and to choose effective coping strategies in dealing with stressful environments as well as being able to reduce the adverse effects they face. The concept of hardiness refers to a combination of self-control, commitment, and self-confidence in facing internal and external pressures (Pourafkari, 2006). Meanwhile according to Taylor, Peplau, and Sears (2009) hardiness is a variable of personality in the form of feelings of commitment, positive response to challenges, and feelings of internal control that assist an individual in dealing with adverse effects effectively.

According to Kobasa (1979) and Maddi, Kobasa, and Kahn (1982) that hardiness aspects are: 1). Commitment is the tendency to involve yourself in whatever is done. People who have a strong commitment will be easily attracted to and sincerely involved in whatever is being done and have a reasonable feeling that will lead him to identify and give meaning to each event and everything in his environment. 2). Control is the tendency to accept and believe that they can control and influence an event with their experience when dealing with unexpected things. People who have active control will always be more optimistic in dealing with problems than people who have weak controls. In solving problems, the ability to control will be able to change each event into something consistent with the planned life goals. 3). Challenge is the tendency to see a change in his life as something natural and can anticipate that change as a stimulus that is very useful for development and sees life as an exciting challenge. Individuals who have substantial challenges will easily find easier ways to eliminate or reduce stressful situations because stress is not considered a threat but as a challenge. The purpose of this study is to determine the effect of self-confidence and hardiness on the work readiness of vocational high school students.

\section{Research methods}

\subsection{Population and samples}

The population in this study was all students of Grade XII State Vocational High School 1 Seyegan. Grade XII in State Vocational High School 1 Seyegan, Sleman Yogyakarta consisting of 14 classes totaling 423 students. Each class consists of 30 students. The sample in this study consisted of 6 classes obtained randomly with 174 students in class XII. The sample selection was made by randomly raffling from 14 classes, which finally got six classes as the research sample.

\subsection{Instruments}

In this study, the work readiness, self-confidence, and hardiness scale take the form of a Likert scale. Work readiness was discovered by using the work readiness scale that refers to aspects of work readiness according to 
Self-confidence and hardiness towards work readiness: Study on vocational high school students

Brady (2009), namely: responsibility, flexibility, skills, speaking ability, self-view, health, and safety. An example of a work readiness scale item is "I complete the assignment on time", "I can do varied tasks", "I can use the practical tools well", "I am willing to accept criticism and feedback from others", I am sure I can do the assignments given, and "I follow safety procedures during fieldwork".

Self-confidence is revealed by using the self-confidence scale that refers to aspects of self-confidence according to Lauster (2012), namely: confidence in one's abilities, act independently in making decisions, have a definite sense of self, and courage to express opinions. An example of an item in the self-confidence scale is "I can do the task on my own", "I set my direction", "I feel optimistic about doing various jobs", and "I dare to express my opinion to friends."

Hardiness was revealed by using the hardiness scale, which refers to hardiness aspects according to Kobasa (1979) and Maddi, Kobasa, and Kahn (1982), namely: commitment, control, and challenge. An example of an item in hardiness scale is "I am involved with various activities in school", "I am calm in solving various problems that I face", and "I feel challenged with various tasks given".

\subsection{Validity and reliability of instruments}

Select items on a scale that is by looking at item discrimination. As the selection criteria for items based on corrected item-total correlation criteria are $\geq .30$. All items that achieve a corrected item-total correlation of at least .30, item discrimination are considered satisfactory. On a scale that does not reach the corrected item-total correlation criteria, the item will be eliminated, because by removing the item, the Cronbach alpha reliability coefficient of the scale will be higher.

On the work readiness scale with 58 test subjects, the reliability coefficient is .87 . The discriminant index (corrected item-total correlation) shifted from .29 to .59 . Twenty-four valid and reliable items were then used in the research.

On the self-confidence scale with 58 test subjects, the reliability coefficient is .85 . The discriminant index (corrected item-total correlation) shifted from .30 to .64. Sixteen valid and reliable items were then used in the research.

On the hardiness scale with 58 test subjects, the reliability coefficient is .84 . The discriminant index (corrected item-total correlation) shifted from .32 to .61. Fifteen valid and reliable items were then used in the research.

\subsection{Data analysis}

Utilizing SPSS 17.0 for Windows, a parametric statistical method was used to analyze the data, namely multiple regressions to see the effect of self-confidence and hardiness on work readiness.

\section{Results}

\subsection{Assumptions tests}

Normality test - Based on the results of the normality test shown in table 1, the significance values of work readiness, self-confidence, and hardiness variables are $.188, .064$ and .138 respectively, with each having $p>.05$ indicating that each data set is normally distributed. This means that there is no difference between sample score and population score distributions; in other words the sample used can represent the population.

Linearity test - The results of the linearity test of self-confidence towards work readiness obtained an $F$ of 59.51 with a significance level (p) of .000, $p<.05$, which indicates linearity or that there is a line that connects 
Tentama, F., Subardjo, S., Mulasari, S. A., \& Merdiaty, N.

the variables of self-confidence with work readiness. The results of the linearity test of hardiness towards work readiness obtained an $F$ of 38.59 with a significance level (p) of $.000, p<.05$, indicating linearity or that there is a straight-line connecting hardiness and work readiness.

Table 1

Normality test

\begin{tabular}{lccc}
\hline \multicolumn{1}{c}{ Variable } & Score K-SZ & Sig. & Annotation \\
\hline Work readiness & 1.09 & .188 & Normal \\
Self-confidence & 1.31 & .064 & Normal \\
Hardiness & 1.16 & .138 & Normal \\
\hline
\end{tabular}

Table 2

Linearity test

\begin{tabular}{lcllc}
\hline \multicolumn{1}{c}{ Variable } & $F$ & Sig. & Criteria & Annotation \\
\hline Self-confidence & 59.51 & .000 & $p<.05$ & Linear \\
Hardiness & 38.59 & .000 & $p<.05$ & Linear \\
\hline
\end{tabular}

Multicollinearity test - The multicollinearity test was conducted to ensure that there was no multicollinearity relationship between the two independent variables. The rule used to determine that there is no multicollinearity relationship: (a) tolerance values must be $>.1$ and, (b) VIF $<10$. Results of the analysis show that self-confidence and hardiness have VIF $=1.11(\mathrm{VIF}<10)$ and tolerance $.91=($ tolerance $>.1)$, indicating no multicollinearity between self-confidence and hardiness.

Table 3

Multicollinearity test

\begin{tabular}{lccc}
\multicolumn{1}{c}{ Variable } & Tolerance & VIF & Annotation \\
\hline Self-confidence & .91 & 1.11 & No multicollinearity \\
Hardiness & .91 & 1.11 & No multicollinearity \\
\hline
\end{tabular}

\subsection{Multiple regression test}

Based on the results of the regression test it was found that the magnitude of the effect of self-confidence on work readiness was $(t)=6.54$ with a significance level of $=.000, p<.01$, meaning that there is a very significant effect on work readiness in students of State Vocational High School 1 Seyegan. Meanwhile, the results of the hardiness regression test on work readiness obtained a value $(\mathrm{t})$ of $=3.80$ with a significance level of $=.000$, $p<.01$, meaning that there is a very significant influence on the hardiness of work readiness in Seyegan 1 Vocational High School students.

\section{Table 4}

Relation between variables

\begin{tabular}{lllll}
\hline \multicolumn{1}{c}{ Variable } & $t$ & Sig. & Criteria & Annotation \\
\hline Self-confidence towards work readiness & 6.54 & .000 & $p<.01$ & Very significant effect \\
Hardiness towards work readiness & 3.80 & .000 & $p<.01$ & Very significant effect \\
\hline
\end{tabular}

The results of the regression analysis simultaneously show an $F$ of $=40.14$ with a significance level of $p=.000, p<.01$, meaning that self-confidence and hardiness simultaneously influence the work readiness of students in State Vocational High School 1 Seyegan. The contribution of the effect of self-confidence and hardiness on work readiness is indicated by the Adjusted R Square $=.31$, meaning that the contribution of the influence of self-confidence and hardiness is $31.1 \%$ and the remaining $68.9 \%$ is influenced by other factors outside the variables studied. 
Self-confidence and hardiness towards work readiness: Study on vocational high school students

Table 5

Multiple regression test

\begin{tabular}{lccccc}
\hline \multicolumn{1}{c}{ Variable } & Adjusted R Square & $F$ & Sig & Criteria & Annotation \\
\hline $\begin{array}{l}\text { Self-confidence and hardiness } \\
\text { towards work readiness }\end{array}$ & .31 & 40.14 & .000 & $p<.01$ & Very significant effect \\
\hline
\end{tabular}

\section{Discussion}

Our findings show that self-confidence and hardiness simultaneously affect the work readiness of students. These results confirm the first hypothesis, meaning that self-confidence and hardiness can predict work readiness. Together, the two independent variables contribute $31.1 \%$ to work readiness, meaning that other variables influence the remaining $68.9 \%$. These other factors could include organizational acumen, social intelligence, characteristics, personal and work competencies (Caballero, Walker, \& Fuller-Tyszkiewicz, 2011). Separately, our study indicates that the contribution of self-confidence towards work readiness is $22.2 \%$, while work readiness contributes $9.7 \%$. Self-confidence has a greater influence on the work readiness of students at State Vocational High School 1 Sayegan compared to hardiness.

Next, the results also confirm the second hypothesis, indicating that self-confidence influences students' hardiness at work. This result is in line with the findings of Cowin and Hengstberger-Sims, (2006) who also supported previous research and expanded understanding of the mechanisms by which an individual's self-confidence effects work readiness. This study is also in line with findings produced by Makki, Salleh, Memon, and Harun, (2015), who found that low levels of self-confidence effects the work readiness of individuals in seeking for jobs. Meanwhile, according to Coetzee and Oosthuizen (2012), high levels of work readiness can be predicted from an individual's confidence in his ability to acquire a job. Students who have self-confidence are students who believe in their abilities, can act independently in making decisions, have a positive sense of themselves, and dare to express their opinions. Thus, students who have confidence will be better prepared to work when they have graduated from Vocational School because they have a sense of responsibility, flexibility, skills, speaking ability, and a (positive) self-view which are characteristics of students who have good work readiness.

Regarding the third hypothesis, results show that there is an effect of hardiness on work readiness of students; thus, accepting the hypothesis. The results are supported by the assumed theory and various previous studies. For instance, van Dyk (2015) found that hardiness can be a predictor of the high and low work readiness of individuals. Individuals with hardiness tend to have high work readiness (Avey, Luthans, Smith, \& Palmer, 2010). According to Huang (2015), one type of personality construct related to work readiness is hardy personality. The concept of hardiness is an attribute that is interrelated with self-control, which is one aspect of work readiness. Self-control represents an individual's belief that they can control the events that occur in their life. Students who show hardiness, namely those who are easily attracted to working on tasks, does not give in to pressure, optimistic, adaptive in shaping their life purpose, flexible, and have excellent stress management, will show better work readiness compared to those without such hardy traits.

Thus, self-confidence and hardiness have an essential role in preparing vocational high school students to work in the industrial world. Students who have work readiness are characterized by their sense of responsibility, flexibility, skills, ability to speak, (positive) self-view, health and safety in carrying out their duties and obligations in school, whether in attending school lessons, practicing in the laboratory, practicing in field works and work internships in industry/companies.

Research on the work readiness of Vocational High School students is still rarely done both in Indonesia and abroad. This study focuses on the work readiness of Vocational High School students. Previous studies only discussed, which is still limited to work readiness on graduates and employees. Previous research focusing on work readiness in graduate and post-graduate studies was conducted by Masole and van Dyk (2016) and research 
by Ramadhania and Dewi (2017) and research by Walker and Campbell (2013). While, work readiness research that focuses on employees is the research of Cavanagh, Burston, Southcombe, and Bartram (2015), and research conducted by Baumann, Crea-Arsenio, Hunsberger, Fleming-Carroll, and Keatings (2019). Besides, the concept of work readiness in this study is the ability of students to be ready to work by showing responsibility, flexibility, skills, communication, self-views, and health and safety.

The implications of this research are for students, parents, and teachers to improve their insight and knowledge about student work readiness. This study shows that self-confidence and hardiness as one form of individual personality has a role for the work readiness of class XII students in supporting the skills, knowledge and understanding that will be applied in the work environment. Parents and teachers must be able to create a positive learning environment at school and home so that it can foster students' self-confidence and hardiness personality. The existence of a positive environment will make students help students foster a sense of confidence and form a hardiness personality so that students can optimally obtain skills, understanding and knowledge to prepare themselves in the world of work. The results of this study can also be used as a reference to develop training modules, specifically training in self-confidence and hardiness training that have contributed to addressing work readiness issues in Vocational High School students.

\section{Conclusion}

Based on our findings, several conclusions can be made: 1) Simultaneously, self-confidence and hardiness have a very significant effect on the work readiness of students in State Vocational High School 1 Sayegan; 2) There is a significant effect of self-confidence on work readiness in students of State Vocational High School 1 Seyegan; and 3) There is a very significant effect of hardiness on the work readiness of State Vocational High School 1 Seyegan student. Self-confidence has a greater influence on the work readiness of students at State Vocational High School 1 Sayegan compared to hardiness.

Acknowledgements: The research reported in this manuscript is part of the fundamental study of the first author, funded by the Institute of Research and Community Service (LPPM) Ahmad Dahan University in letter Number PF-109/SP3/LPP-UAD/IV/2017. Appreciation goes to funder and research respondents.

\section{References}

Andrews, J., \& Higson, H. (2008). Graduate employability, 'soft skills' versus 'hard' business knowledge: A European study. Higher Education in Europe, 33(4), 411-422. https://doi.org/10.1080/03797720802522627

Avey, J. B., Luthans, F., Smith, R. M., \& Palmer, N. F. (2010). Impact of positive psychological capital on employee well-being over time. Journal of Occupational Health Psychology, 15(1), 17-28. https://doi.org/10.1037/a0016998

Bandaranaike, S., \& Willison, J. W. (2015). Building capacity for work-readiness: Bridging the cognitive and affective domains. Asia-Pacific Journal of Cooperative Education, 16(3), 223-233.

Bartone, P. T. (2006). Resilience under military operational stress: Can leaders influence hardiness? Military Psychology, 18(1), 131-148. https://doi.org/10.1207/s15327876mp1803s_10

Baumann, A., Crea-Arsenio, M., Hunsberger, M., Fleming-Carroll, B., \& Keatings, M. (2019). Work readiness, transition, and integration: The challenge of specialty practice. Journal of Advanced Nursing, 75(4), 823-833. https://doi.org/10.1111/jan.13918

Bearden, W. O., Hardesty, D. M., \& Rose, R. L. (2001). Consumer self-confidence: Refinements in conceptualization and measurement. Journal of Consumer Research, 28(1), 121-134. https://doi.org/10.1086/321951

Brown, D., \& Chronister, C. (2009). The effect of simulation learning on critical thinking and self-confidence when incorporated into an electrocardiogram nursing course. Clinical Simulation in Nursing, 5(1), 
Self-confidence and hardiness towards work readiness: Study on vocational high school students

45-52. https://doi.org/10.1016/j.ecns.2008.11.001

Caballero, C. L., Walker, A., \& Fuller-Tyszkiewicz, M. (2011). The work readiness scale (WRS): Developing a measure to assess work readiness in college graduates. Journal of Teaching and Learning for Graduate Employability, 2(2), 41-54. https://doi.org/10.21153/jtlge2011vol2no1art552

Cabellero, C. L., \& Walker, A. (2010). Work readiness in graduate recruitment and selection: A review of current assessment methods. Journal of teaching and learning for graduate employability, 1(1), 13-25. https://doi.org/10.21153/jtlge2010vol1no1art546

Casner-Lotto, J., \& Barrington, L. (2006). Are they really ready to work? New York: The Conference Board, Inc.

Cavanagh, J., Burston, M., Southcombe, A., \& Bartram, T. (2015). Contributing to a graduate-centred understanding of work readiness: An exploratory study of Australian undergraduate students' perceptions of their employability. The International Journal of Management Education, 13(3), 278-288. https://doi.org/10.1016/j.ijme.2015.07.002.

Central Bureau of Statistics. (2018). Open unemployment according to the highest education completed in 1986-2018 [Pengangguran terbuka menurut pendidikan tertinggi yang ditamatkan 1986-2018].

Retrieved from https://www.bps.go.id/statictable/2009/04/16/972/pengangguran-terbuka-menurut-pendidikan-tertinggiyang-ditamatkan-1986---2018.html

Clark, H. (2015). Building a common language for career readiness and success: A foundational competency framework for employers and educators. ACT Working Paper Series, 1-14.

Coetzee, M., \& Esterhuizen, K. (2010). Psychological career resources and coping resources of the young unemployed African graduate: An exploratory study. SA Journal of Industrial Psychology, 36(1), 1-9. https://doi.org/10.4102/sajip.v36i1.868

Coetzee, M., \& Oosthuizen, R. M. (2012). Students' sense of coherence, study engagement and self-efficacy in relation to their study and employability satisfaction. Journal of Psychology in Africa, 22(3), 315-322. https://doi.org/10.1080/14330237.2012.10820536

Cowin, L. S., \& Hengstberger-Sims, C. (2006). New graduate nurse self-concept and retention: A longitudinal survey. International Journal of Nursing Studies, 43(1), 59-70. https://doi.org/10.1016/j.ijnurstu.2005.03.004

Huang, J. T. (2015). Hardiness, perceived employability, and career decision self-efficacy among Taiwanese college students. Journal of Career Development, 42(4), 311-324. https://doi.org/10.1177/0894845314562960

Innes, E., \& Straker, L. (2002). Workplace assessments and functional capacity evaluations: current practices of therapists in Australia. Work, 18(1), 51-66.

Jollands, M., Jolly, L., \& Molyneaux, T. (2012). Project-based learning as a contributing factor to graduates' work readiness. European Journal of Engineering Education, 37(2), 143-154. https://doi.org/10.1080/03043797.2012.665848

Kobasa, S. C. (1979). Stressful life event, personality and health: An inquiry into hardiness. Journal of Personality and Social Psychology, 37(1), 1-11. http://dx.doi.org/10.1037/0022-3514.37.1.1

Landrum, R. E., Hettich, P. I., \& Wilner, A. (2010). Alumni perceptions of workforce readiness. Teaching of Psychology, 37(2), 97-106. http://dx.doi.org/10.1080/00986281003626912

Lauster. (2012). The personality test (Tes kepribadian). Jakarta: Bumi Aksara.

Li, E. J., Li-Tsang, C. W., Lam, C. S., Hui, K. Y., \& Chan, C. C. (2006). The effect of a "training on work readiness" program for workers with musculoskeletal injuries: a randomized control trial (RCT) study. Journal of Occupational Rehabilitation, 16(4), 529-541. http://dx.doi.org/10.1007/s10926-006-9034-3

Luthans, F., Luthans, K. W., \& Luthans, B. C. (2004). Positive psychological capital: Beyond human and social capital. Business Horizons, 47, 45-50. http://dx.doi.org/10.1016/j.bushor.2003.11.007

Maddi, S. R. (2012). Hardiness: Turning stressful circumstances into resilient growth. New York: Springer Science \& Business Media.

Maddi, S. R., Kobasa, S. C., \& Kahn, S. (1982). Hardiness and health: A prospective study. Journal of 
Tentama, F., Subardjo, S., Mulasari, S. A., \& Merdiaty, N.

Personality and Social Psychology, 42, 168-177. http://dx.doi.org/10.1037/0022-3514.42.1.168

Maddi, S. R., Matthews, M. D., Kelly, D. R., Villarreal, B., \& White, M. (2012). The role of hardiness and grit in predicting performance and retention of USMA cadets. Military Psychology, 24(1), 19-28. https://doi.org/10.1080/08995605.2012.639672

Makki, B. I., Salleh, R., Memon, M. A., \& Harun, H. (2015). The relationship between work readiness skills, career self-efficacy and career exploration among engineering graduates: A proposed framework. Research Journal of Applied Sciences, Engineering and Technology, 10(9), 1007-1011. https://doi.org/10.19026/rjaset.10.1867

Masole, L., \& van Dyk, G. (2016). Factors influencing work readiness of graduates: An exploratory study. Journal of Psychology in Africa, 26(1), 70-73. https://doi.org/10.1080/14330237.2015.1101284

Mason, G., Williams, G., \& Cranmer, S. (2009). Employability skills initiatives in higher education: what effects do they have on graduate labor market outcomes? Education Economics, 17(1), 1-30. https://doi.org/10.1080/09645290802028315

McGee, J. E., Peterson, M., Mueller, S. L., \& Sequeira, J. M. (2009). Entrepreneurial self-efficacy: Refining the measure. Entrepreneurship Theory and Practice, 33(4), 965-988. https://doi.org/10.1111/j.1540-6520.2009.00304.x

Özbey, Ç. (2004). Çocuk sorunlarına yapıcı çözümler [Constructive solutions to child problems]. İstanbul: İnkılâp Kitabevi.

Pourafkari, N. A. (2006). Comprehensive dictionary of psychology-psychiatry and related issues. Tehran: Farhang.

Raftopoulos, M., Coetzee, S., \& Visser, D. (2009). Work-readiness skills in the Fasset Sector. SA Journal of Human Resource Management, 7(1), 119-126. https://doi.org/10.4102/sajhrm.v7i1.196

Ramadhania, C. K., \& Dewi, M. S. (2017). Impact of goal orientation, personality types and campus climate at UIN Syarif Hidayatullah Jakarta nursing student's work readiness. TAZKIYA Journal of Psychology, 5(2), 179-190.

Taylor, S., Peplau, L., \& Sears, D. (2009). Social psychology. Englewood Cliffs: Prentice Hall.

Van Dyk, G. (2015). Hardiness as predictor of work readiness: A preliminary exploratory study. Journal of Psychology in Africa, 25(1), 80-82. https://doi.org/10.1080/14330237.2014.997031

Walker, A. \& Campbell, K. (2013). Work readiness of graduate nurses and the impact on job satisfaction, work engagement and intention to remain. Nurse Education Today, 33(12), 1490-1495. https://doi.org/10.1016/j.nedt.2013.05.008 